\title{
Proefschrift
}

\section{In-training assessment in an undergraduate clerkship. Feasibility, reliability, effect on learning environment}

Daelmans HEM (29 juni 2005). In-training assessment in an undergraduate clerkship. Feasibility, reliability, effect on learning environment. Vrije Universiteit, Amsterdam. Promotoren: prof. dr. C.D.A. Stehouwer, prof. dr. C.P.M. van der
Vleuten. Co-promotoren: prof. dr. A.J.J.A. Scherpbier, prof. dr. A.J.M. Donker. Enschede: Febodruk $B V ;$ 2005. 175 pagina's. ISBN 90-9018489-4. Beschikbaar op: http://www.ubvu.vu.nl/dissertations.

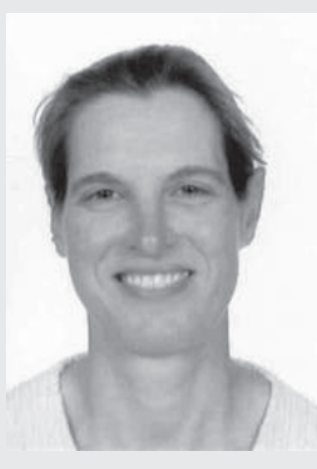

\begin{tabular}{|c|c|}
\hline Naam & Hester Elisabeth Maria Daelmans \\
\hline $1981-1988$ & $\begin{array}{l}\text { Geneeskundestudie aan de Katholieke Universiteit } \\
\text { Nijmegen }\end{array}$ \\
\hline $1991-2004$ & $\begin{array}{l}\text { Diverse onderwijskundige cursussen en workshops } \\
\text { SMO en NVMO }\end{array}$ \\
\hline Werkplek & $\begin{array}{l}\text { Onderwijsinstituut, sectie ALCO, Vrije Universiteit } \\
\text { medisch centrum te Amsterdam }\end{array}$ \\
\hline Functie & Hoofd sectie ALCO \\
\hline $\begin{array}{l}\text { Onderzoeks- } \\
\text { thema's }\end{array}$ & $\begin{array}{l}\text { Toetsing in de coassistentschappen, leeromgeving in } \\
\text { de coassistentschappen }\end{array}$ \\
\hline
\end{tabular}

Inleiding: Leren in de coassistentschappen vormt een onmisbare schakel in het verwerven van competenties door studenten geneeskunde. De leeromgeving in de coassistentschappen is echter complex en verre van optimaal. Supervisie en feedback zijn essentiële componenten voor een goede leeromgeving. De frequentie van supervisie en feedback in coassistentschappen is echter laag en er is weinig structuur in supervisie en feedback. Toetsing is beschreven als een krachtig instrument om gedrag van studenten (en van docenten) te sturen en kan dan ook strategisch ingezet worden om de leeromgeving in coassistentschappen te verbeteren. De toetsing van competenties in de coassistentschappen is niet eenvoudig. De toetsvormen die gebruikt worden om competenties te meten, hebben vaak een geringe betrouwbaarheid. Maatregelen om de betrouwbaarheid te vergroten, zoals het structureren van toetsen, vaker toetsen en het inzetten van meer examinatoren, hebben vaak een negatief effect op de haalbaarheid. Er is dan ook behoefte aan een betrouwbare toetsvorm die op een haalbare wijze competenties van coassistenten toetst en die de leeromgeving positief beïnvloedt. In-training assessment (ITA) heeft potentie als een betrouwbare toetsvorm van competenties, alsook als instrument om de leeromgeving positief te beïnvloeden. ITA wordt gedefinieerd als meerdere gestructureerde en waar mogelijk geobserveerde toetsmomenten die onmiddellijk na het toetsmoment gedocumenteerd worden en die verspreid over het hele coassistentschap plaatsvinden.

Vraagstellingen: Het proefschrift concentreert zich rond twee vraagstellingen:

1. De haalbaarheid en betrouwbaarheid van verschillende toetsvormen geschikt voor ITA.

2. De effecten van een ITA-programma op de leeromgeving in een coassistentschap. 
Haalbaarheid en betrouwbaarheid van verschillende toetsvormen geschikt voor ITA: Drie toetsvormen (meerdere patiëntgebonden examens, een ITA-programma en meerdere globale beoordelingen) werden onderzocht in het coassistentschap inwendige geneeskunde in het Vrije Universiteit medisch centrum (Vumc) te Amsterdam. Het ontwerp en de implementatie van de nieuwe toets- en beoordelingsvormen gebeurde in nauw overleg met de beoogde examinatoren. Aspecten van haalbaarheid en betrouwbaarheid waren zorgvuldig betrokken in het ontwerp.

De haalbaarheid en betrouwbaarheid van de meerdere patiëntgebonden examens én van het ITA-programma waren goed. De betrouwbaarheid van de globale beoordelingen was slecht, hoewel ze enige voorspellende waarde bleken te hebben voor het ITA-programma.

Het zorgvuldig ontwerp en het intensief overleg met de examinatoren bleek vruchten af te werpen voor meerdere patiëntgebonden examens en voor het ITA-programma. Het ITA-programma kan verder verbeteren door het incorporeren van meerdere korte toetsmomenten, het integreren van globale beoordelingen in het programma, het expliciet inroosteren van toetstijd (inclusief tijd voor feedback) en het verzamelen van de toetsresultaten in een portfolio.

Effect van een ITA- programma op de leeromgeving: Als eerste werd de kwaliteit van de leeromgeving in drie traditionele coassistentschappen, te weten inwendige geneeskunde, heelkunde en kindergeneeskunde, in het VUmc bepaald. Coassistenten vulden enquêtes in met parameters over de kwaliteit van de leeromgeving (supervisie en feedback) in het coassistentschap. In de onderzochte disciplines werden coassistenten weinig gesuperviseerd en vooral weinig geobserveerd. Feedback werd voornamelijk gegeven door artsassistenten. Voor alle variabelen waren de individuele verschillen groter dan de verschillen tussen de disciplines. Adequate competentieverwerving was dan ook niet gegarandeerd in deze coassistentschappen. Verbetering van de frequentie van supervisie en feedback alsook van de eenvormigheid van het aangeboden onderwijsprogramma is daarom gewenst.

Vervolgens werd dezelfde enquête afgenomen na implementatie van het ITA-programma in het coassistentschap inwendige geneeskunde in het VUmc. De verwachting was dat het ITA-programma een positief effect zou hebben op de frequentie van supervisie en feedback, omdat het supervisie- en feedbackmomenten incorpo- reert én omdat de toetsing van een grote groep competenties het gedrag van studenten en docenten kan sturen richting deze competenties. Op basis van de enquêtes kon er echter voor geen enkele variabele een significante toename worden geconstateerd. Deze uitkomst was aanleiding tot twijfel over het toetsprogramma in actie (i.t.t. het beoogde toetsprogramma) en over de sensitiviteit van de onderzoeksmethode om verschillen te detecteren na implementatie van het ITA-programma.

Om deze reden werd ten slotte een kwalitatieve studie van de leeromgeving na invoering van het ITA-programma uitgevoerd. Uit semigestructureerde interviews met studenten, artsassistenten en stafleden bleek dat het toetsprogramma in actie suboptimaal werd uitgevoerd. Een gebrek aan voortdurende informatie en controle was hier debet aan. Verder kwamen de effecten van het ITA-programma op de leeromgeving onvoldoende uit de verf. Tijdgebrek, beperkte contacten met studenten en onzekerheid over hoe precies supervisie en feedback te geven, weerhielden artsassistenten en stafleden om meer te superviseren en adequate feedback te geven. Het expliciet inplannen van tijd tussen supervisor en coassistent en het trainen van supervisoren in supervisie en feedback kan de gewenste effecten van toetsing op de leeromgeving bevorderen.

Conclusie en implicatie: De betrouwbaarheid van competentietoetsen is te verbeteren zonder de haalbaarheid te benadelen. Toetsing kan verder worden geoptimaliseerd door een veelvoud van (korte) toetsvormen te combineren met globale beoordelingen en waar mogelijk ook met portfoliotoetsing.

Als toetsing wordt ingezet om de leeromgeving te verbeteren, dan is het belangrijk gebruikers doorlopend te informeren en de uitvoering van het toetsprogramma voortdurend te volgen. Daarnaast is het nodig de gewenste effecten op de leeromgeving te ondersteunen door bijvoorbeeld trainingen aan te bieden of werkomstandigheden te optimaliseren.

Om een verbetering van de leeromgeving te bereiken, zijn naast onderwijskundige maatregelen ook politieke en financiële maatregelen noodzakelijk. De ontwikkeling van een strategie om onderwijs net zo belangrijk te maken als patiëntenzorg en onderzoek is essentieel. Daarnaast dient de kloof tussen onderwijskunde en medische praktijk geëxpliciteerd en gedicht te worden door aandacht voor en identificatie van gemeenschappelijke problemen. 